\title{
Immeasurably Low and Non-TRH-stimulatable TSH Associated with Normal I-123 Uptake in Two Goitrous Euthyroid Patients: Possible Existence of Other Thyroid-hormone Regulated Thyroid Stimulators other than TSH
}

\author{
Katsuji IKEKUBO, MEgumu HINO*, YASUhiko SAIKI*, CheOl SON**, ToShio IWAKURA**, \\ HIROMASA KOBAYASHI** AND TAKASHI ISHIHARA** \\ Hyogo Health Service Association, Kobe 658-0046, Japan \\ *Department of Nuclear Medicine, Kobe City General Hospital, Kobe 650-0046, Japan \\ **Department of Endocrinology, Kobe City General Hospital, Kobe 650-0046, Japan
}

\begin{abstract}
We described two euthyroid patients with normally functioning goiters, but with persistently undetectable and non-stimulatable TSH levels. Subject 1 was a 64-year-old woman with a large diffuse goiter who has been clinically and biochemically euthyroid without any medication for at least 19 years. Subject 2 was a 31 -year-old woman with a small diffuse goiter who has been euthyroid for 4 years. Both patients had persistently undetectable levels of serum TSH, TSH receptor antibodies (TRAb) and thyroid stimulating antibodies (TSAb). Their basal TSH levels were very low and their $\mathrm{T}_{3}$ responses to TRH were very diminished or absent. In contrast, the basal levels of the other pituitary hormones and their responses to LHRH, GRH and CRH stimulation were all within normal limits in both patients. MRI images of pituitary glands, ${ }^{123} \mathrm{I}$ thyroid uptake, and thyroid scans were normal. Ectopic thyroids were not detected on ${ }^{99 \mathrm{~m}} \mathrm{TcO}_{4}^{-}$and ${ }^{123} \mathrm{I}$ total body scans. Factors interfering with the measurement of TSH were excluded by recovery studies. In subject 1 a $T_{3}$ suppression test was positive and a perchlorate discharge test was negative. In subject $2 \mathrm{a} \mathrm{T}_{3}$-suppression test was negative. Euthyroid Graves' disease, subclinical hyperthyroidism, destructive thyroiditis, thyrotoxicosis of extrathyroid origin, central hypothyroidism, and nonthyroidal illness were all ruled out by these observations. These results suggest that an unknown factor, such as thyrostimulin, but not TSH or TSAb, stimulates the thyroid and maintains euthyroidism, and may have a role in the regulation of the hypothalamus-pituitary-thyroid axis.
\end{abstract}

Key words: Long-term low TSH, Euthyroid goiter, No response of TSH to TRH, No elevation of $\mathrm{T}_{3}$ to TRH

(Endocrine Journal 52: 61-68, 2005)

THE function of the thyroid gland is regulated primarily by TSH from the pituitary gland, which in turn is regulated by TRH from the hypothalamus. Low serum TSH levels are observed in overt hyperthyroidism, treated Graves' disease, euthyroid Graves' disease [1], subclinical hyperthyroidism [2], destructive thyroiditis [3], and thyrotoxicosis of extrathyroidal origin (thyrotoxicosis factitia [4], metastatic thyroid carcinoma [5],

Received: May 20, 2004

Accepted: November 1, 2004

Correspondence to: Dr. Katsuji IKEKUBO, Hyogo Health Service Association, 4-4-20, Mikage-honmachi, Higashinada-ku, Kobe 658-0046, Japan struma ovarii $[6,7]$ ), central hypothyroidism [8], nonthyroidal illness [9] and aging [10]. Usually it is not difficult to determine the cause of low serum TSH levels.

We report here two unusual euthyroid patients with goiters and persistently undetectable TSH levels. We consider the clinical significance of the association of goiter with long-term undetectable TSH and normal thyroid hormone levels and the possible implications for the hypothalamus-pituitary-thyroid axis. Since the cause of the low TSH could not be determined after extensive evaluation, it is suggested that there are factors in addition to TSH that contribute to the control of the thyroid gland. 


\section{Subjects and Methods}

\section{Subject 1}

A 64-year-old housewife presented for evaluation of goiter at age 42, in December, 1982. The goiter was first noted during a medical checkup when she was 35 years old, but as she was healthy and had no complaints, no further evaluation was performed at that time. At the first visit to our hospital she was clinically euthyroid with normal intelligence. The thyroid gland was soft and diffusely enlarged $(5.6 \mathrm{~cm}$ in width). There were no ophthalmological abnormalities. There were no hereditary or thyroid disorders in her family. She had a hysterectomy and ovariectomy for myoma of uterus at age 45. At the time of her first visit the serum $\mathrm{T}_{4}$ was $8.9 \mu \mathrm{g} / \mathrm{dL}$ (5.9-12.3, normal range), $\mathrm{T}_{3} 1.43 \mathrm{ng} /$ $\mathrm{mL}(0.8-1.8)$ and TSH was $0.38 \mu \mathrm{U} / \mathrm{mL}(0.48-4.2)$.

At her first visit a Silverman needle percutaneous biopsy of her thyroid revealed minimal fibrosis and partially damaged colloid-filled follicles of varying sizes. There was no lymphocytic infiltration and no epithelial cell degeneration (Fig. 1). Following the first visit she was treated with low-dose $\mathrm{L}_{-} \mathrm{T}_{4}(25-50 \mu \mathrm{g} /$ day), but only for 2 years. Since then she has been followed up every 3-6 months for the past 19 years, and has remained euthyroid without any thyroid-related medication. TSH has been undetectably low and TRAb and TSAb have been repeatedly negative. She remains asymptomatic except for goiter. She was admitted to our hospital in June, 2003 for further evaluation of low TSH.

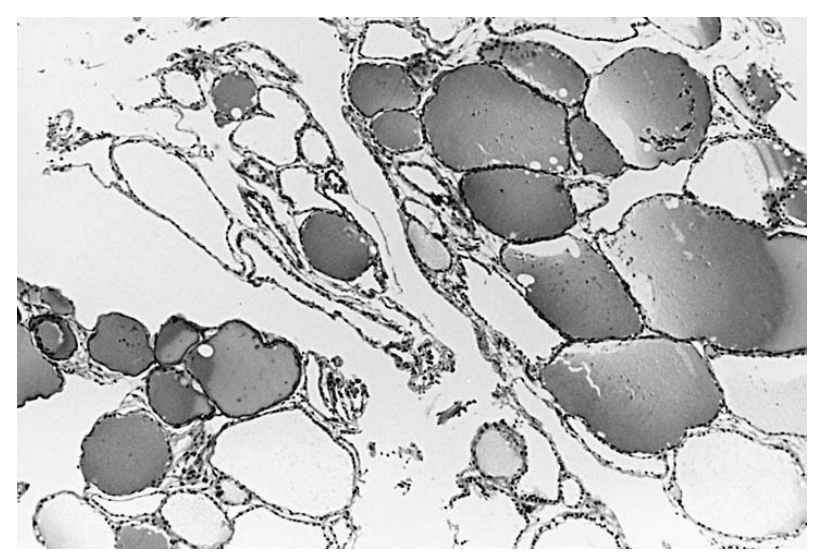

Fig. 1. Histology of the thyroid gland of subject 1 obtained by core needle biopsy in January, 1983 (HE stain, $\times 100$ ).
Subject 2

A 31-year-old woman was referred at age 29 in November, 1999 for evaluation of low TSH. She had been in good health with no history of thyroid or other diseases. Since age 25 she had occasionally underwent Kaufmann treatment (estrogen and ethinylestradiol) for idiopathic amenorrhea [11]. She was found to have undetectable TSH and normal thyroid hormone levels at age 29. She had a small diffuse goiter and was clinically euthyroid. She was admitted to our hospital on July, 2002 for evaluation of her low TSH.

\section{Measurement of hormones and other substances}

Serum $\mathrm{FT}_{4}, \mathrm{FT}_{3}$ and TSH levels were measured by immunoradiometric assay (IRMA) using AmerlexMAB $\mathrm{FT}_{3}, \mathrm{FT}_{4}$ kits (Ortho-Clinical Diagnostics, Tokyo, Japan) and RIA-gnost TSH IRMA (CIS Bio International, France). The third generation immunochemiluminometric TSH assays BeriLux TSH (Hoechst Co., Germany) and Vitros TSH (Ortho-Clinical Diagnostics, Tokyo, Japan) were also used. The lowest detectable level of TSH was $0.10,0.017$ and $0.03 \mu \mathrm{U} / \mathrm{mL}$ for RIA-gnost TSH, BeriLux TSH, and Vitros TSH, respectively. Serum $\mathrm{T}_{3}$ level was measured by T-3 RIA bead radioimmunoasay kit (Abbott Japan Co.). Reference range were: $\mathrm{FT}_{4}, 0.98-1.90 \mathrm{ng} / \mathrm{dL} ; \mathrm{FT}_{3}, 3.30-4.93$ $\mathrm{pg} / \mathrm{mL} ; \mathrm{T}_{3}, 0.8-1.8 \mathrm{ng} / \mathrm{mL}$; RIA-gnost TSH, 0.48-4.2 $\mu \mathrm{U} / \mathrm{mL}$; BeriLux TSH, 0.60-3.66 $\mu \mathrm{U} / \mathrm{mL}$; Vitros TSH, $0.44-4.03 \mu \mathrm{U} / \mathrm{mL}$. The third generation TSH assay was used for the in vitro recovery study of TSH, the TRH test and the $\mathrm{T}_{3}$ suppression test. Anti-TSH receptor antibody (TRAb) was assayed using the TRAb Cosmic II kit (Cosmic Co., Tokyo, Japan) and a newly developed sensitive TRAb assay kit DYNO test TRAb human (Yamasa Corp., Tokyo, Japan). Normal range for TRAb is $<10 \%$ and is $<15 \%$ for TRAb Cosmic II and DYNO test TRAb human. Thyroid-stimulating antibody (TSAb) activities were measured using cultured porcine thyrocytes [12] with a normal range of $<180 \%$.

\section{In vitro studies}

Human anti-mouse antibodies (HAMA) were measured using an RF/HAMA one step kit (MP-Product, Netherlands). The existence of anti-bovine TSH antibody was examined using the TRAb Cosmic II kit 
without the addition of the TSH receptor provided.

An in vitro recovery test was performed to exclude the presence of an inhibitor of endogenous TSH. We assessed the recovery of TSH by adding standard hTSH at four levels to serum from the two subjects. The recovery of the TSH added to each of the two subjects's serum (baseline TSH for both subjects $<0.03$ $\mu \mathrm{U} / \mathrm{mL}$ ) was determined.

\section{Sequencing of the TSH $\beta$ gene}

Blood samples were obtained from subject 1 after obtaining informed consent.

Genomic DNA was isolated from peripheral blood leukocytes using a phenol-chloroform extraction method prepared from leukocytes from subject 1. Exon 1, 2 and 3 of the TSH $\beta$ gene were amplified using PCR and the PCR products were directly sequenced using the DYEnamic ET terminator Cycle Sequencing Kit (Amersham Biosciences, NJ, USA) and an ABI PRISM 3100 Genetic Analyzer (Applied Biosystems, CA, USA).

\section{TRH, LHRH , GRH and CRH stimulation tests}

Serum TSH, $\mathrm{T}_{3}, \mathrm{PRL}, \mathrm{LH}, \mathrm{FSH}, \mathrm{GH}, \mathrm{ACTH}$ and cortisol levels were determined before and 30, 60, 90 and $120 \mathrm{~min}$ after iv injection of $500 \mu \mathrm{g}$ TRH, $100 \mu \mathrm{g}$ LHRH, GRH and CRH. The mean increment in TSH (mean $\triangle \mathrm{TSH}$ ) was calculated by averaging the increments at 30, 60, 90 and $120 \mathrm{~min}$. The serum $\mathrm{T}_{3}$ increment $\left(\Delta \mathrm{T}_{3}\right)$ was measured $120 \mathrm{~min}$ after TRH administration.

\section{In vivo thyroid studies}

To evaluate the function and structure of the patients' thyroid glands, thyroid uptake and imaging with ${ }^{123} \mathrm{I}$ and ${ }^{99} \mathrm{~m}^{1} \mathrm{TcO}_{4}^{-}$were performed using a gamma camera. The ${ }^{123}$ I thyroid uptake and image were obtained at 3 and 24 hours after oral administration of $3.7 \mathrm{MBq}$ of $\mathrm{Na}^{123} \mathrm{I}$ after avoiding high iodine foods for 10 days. For ${ }^{99} \mathrm{mcO}_{4}^{-}, 185 \mathrm{MBq}$ were injected intravenously and thyroid uptakes and images were obtained at $20 \mathrm{~min}$. The normal range was $7-35 \%$ for 24 -hour ${ }^{123} \mathrm{I}$ and 0.4 $2.5 \%$ for ${ }^{99} \mathrm{mcO}_{4}{ }^{-}$thyroid uptake. To detect ectopic thyroid, total body scans were performed just after ${ }^{123} \mathrm{I}$ and ${ }^{99} \mathrm{TcO}_{4}{ }^{-}$thyroid uptake.

In the $\mathrm{T}_{3}$ suppression test, $25 \mu \mathrm{g} \mathrm{T}_{3}$ was administered orally three times daily for 7 days, and serum thyroid hormones, TSH, total cholesterol, triglyceride, alkaline phosphatase and ferritin were measured. Normally the 24-hour ${ }^{123}$ I thyroid uptake in the thyroid falls by more than $50 \%$ of thyroid uptake before $\mathrm{T}_{3}$ administration.

The perchlorate discharge test was used to evaluate intrathyroidal iodide organification. For this test, the thyroid uptake was measured at 24 hours after oral administration of $3.7 \mathrm{MBq} \mathrm{Na}{ }^{123} \mathrm{I}$ and then at 30 and $60 \mathrm{~min}$ after orally administering $1 \mathrm{~g}$ of potassium perchlorate. The test is positive (abnormal) if more than $10 \%$ of the radioactivity of the 24 -hour uptake is discharged from the gland. The mean \pm S.D. maximal discharge was $4.5 \pm 4.3 \%$ (range, $0-9.9 \%$ ) in 7 control subjects with nontoxic diffuse goiter who were evaluated at our hospital during the last 10 years.

\section{Statistical analysis}

All experimental results are presented as mean \pm S.D. Serum samples were obtained from subjects after obtaining informed consent.

\section{Results}

\section{Clinical studies}

\section{Subject 1}

On admission her height was $146 \mathrm{~cm}$ and she weighed $49 \mathrm{~kg}$. Her pulse was $70 / \mathrm{min}$ and regular, her blood pressure was $126 / 70 \mathrm{mmHg}$ and her skin and hair were of normal consistency. Her thyroid gland was diffusely enlarged $(6.0 \mathrm{~cm}$ width $)$. All of the patient's kindred are healthy and her son has normal free thyroid hormones and TSH levels.

This subject's serum $\mathrm{FT}_{4}, \mathrm{FT}_{3}$ and $\mathrm{T}_{3}$ levels were normal, $1.34 \pm 0.19 \mathrm{ng} / \mathrm{dL}$ (range $1.0-1.71 \mathrm{ng} / \mathrm{dL}$ ), 3.76 $\pm 0.48 \mathrm{pg} / \mathrm{mL}$ (range $3.0-4.7 \mathrm{pg} / \mathrm{mL}$ ) and $1.20 \pm 0.29$ $\mathrm{ng} / \mathrm{mL}$ (range $0.74-1.65 \mathrm{ng} / \mathrm{mL}$ ), respectively, and her TSH levels were always less than the least detectable level of $0.1 \mu \mathrm{U} / \mathrm{mL}$ (Fig. 2, left upper panel). During 1990-2003 serum total cholesterol, triglyceride and alkaline phosphatase were normal, at $183 \pm 10 \mathrm{mg} /$ dL (range 166-200 mg/dL), $59 \pm 24 \mathrm{mg} / \mathrm{dL}$ (range 34$126 \mathrm{mg} / \mathrm{dL}$ ) and $149 \pm 18 \mathrm{IU} / \mathrm{L}$ (range 129-190 IU/L), respectively. In 1988 the TSH response to TRH was $<0.14 \mu \mathrm{U} / \mathrm{mL}(0 \mathrm{~min}), 1.64 \mu \mathrm{U} / \mathrm{mL}$ (30 min) and 1.46 $\mu \mathrm{U} / \mathrm{mL}$ (60 $\mathrm{min}$ ) by RIA-gnost TSH IRMA and 0.23 

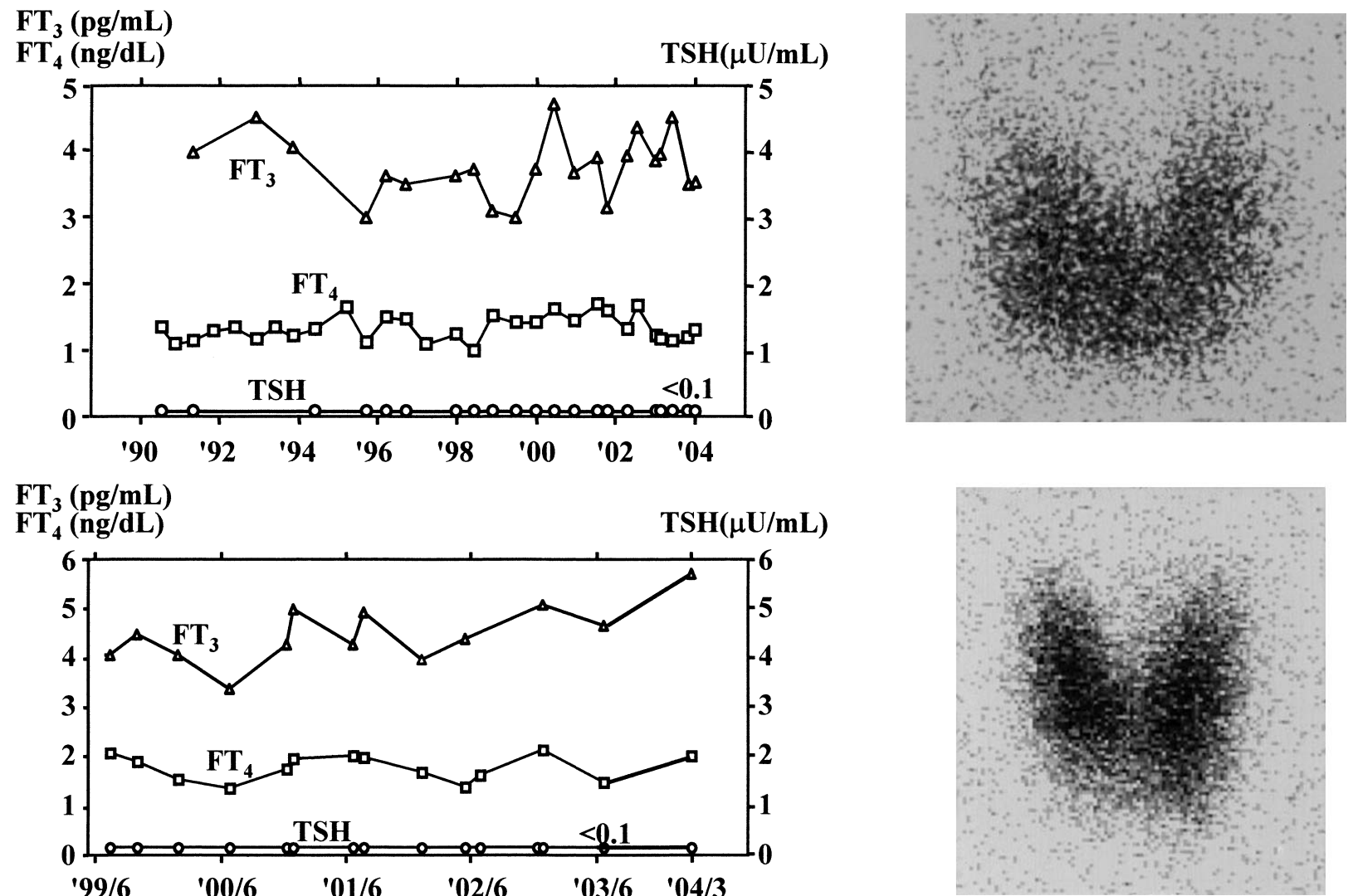

Fig. 2. Clinical courses and ${ }^{123} \mathrm{I}$-images of subject 1 (upper panel) and subject 2 (lower panel). Units of the vertical axis are pg/mL for $\mathrm{FT}_{3}(\triangle), \mathrm{ng} / \mathrm{dL}$ for $\mathrm{FT}_{4}(\square)$ and $\mu \mathrm{U} / \mathrm{mL}$ for TSH $(\mathbf{O})$. Images were obtained at 24 hours when the uptake in subject 1 (in 2003 ) was $17.9 \%$ and the uptake in subject 2 (in 2002) was $21.7 \%$.

$\mu \mathrm{U} / \mathrm{mL}(0 \mathrm{~min}), 2.28 \mu \mathrm{U} / \mathrm{mL}(30 \mathrm{~min})$ and $1.98 \mu \mathrm{U} / \mathrm{mL}$ (60 min) by BeriLux TSH.

\section{Subject 2}

Her height was $153 \mathrm{~cm}$ and she weighed $46.3 \mathrm{~kg}$. Her pulse rate was $68 / \mathrm{min}$ with regular rhythm and her blood pressure was $104 / 80 \mathrm{mmHg}$. The only abnormal physical finding was a small diffuse goiter.

During 4 years of observation this subject's $\mathrm{FT}_{4}, \mathrm{FT}_{3}$ and $\mathrm{T}_{3}$ levels were $1.70 \pm 0.26 \mathrm{ng} / \mathrm{dL}$ (range 1.30 $2.06 \mathrm{ng} / \mathrm{dL}$ ), $4.41 \pm 0.59 \mathrm{pg} / \mathrm{mL}$ (range $3.30-5.59 \mathrm{pg} /$ $\mathrm{mL}$ ) and $1.33 \pm 0.18 \mathrm{ng} / \mathrm{mL}$ (range $1.07-1.64 \mathrm{ng} / \mathrm{mL}$ ), respectively, with persistently undetectable TSH levels (Fig. 2, left lower panel). During observation her serum total cholesterol, triglyceride and alkaline phosphatase were normal, $184 \pm 18 \mathrm{mg} / \mathrm{dL}$ (range 156-212 $\mathrm{mg} / \mathrm{dL}$ ), $66 \pm 19 \mathrm{mg} / \mathrm{dL}$ (range $39-101 \mathrm{mg} / \mathrm{dL}$ ) and $81 \pm 30 \mathrm{IU} / \mathrm{L}$ (range 57-133 IU/L). Her mother has Hashimoto's thyroiditis and her brother has thyroid dysfunction.
The baseline admission laboratory measurements for both subjects are shown in Table 1. Their $\mathrm{FT}_{4}$ and $\mathrm{FT}_{3}$ levels were normal, but TSH was undetectable. In both subjects their TRAb and TSAb levels were negative. Subject 2 has anti-Tg antibodies.

The results of the TRH, LHRH, GRH and CRH stimulation tests are shown in Table 2. TRH stimulation increased serum TSH minimally in subject 1 from $<0.03$ to 0.78 , and not at all in subject 2. Mean TSH changes $(\Delta \mathrm{TSH})$ in subjects 1 and 2 were $0.54 \mu \mathrm{U} /$ $\mathrm{mL}$ and $0 \mu \mathrm{U} / \mathrm{mL}$ respectively, significantly less than the change in controls $(16.1 \pm 6.7 \mu \mathrm{U} / \mathrm{mL})$. The serum $\mathrm{T}_{3}$ increment at $120 \mathrm{~min}$ after TRH $\left(\Delta \mathrm{T}_{3}\right)$ in subject 1 was $0.03 \mathrm{pg} / \mathrm{mL}$ and in subject 2 was $0.01 \mathrm{pg} / \mathrm{mL}$, both significantly less than that in the controls $(0.23 \pm$ $0.12 \mathrm{pg} / \mathrm{mL}$ ). Prolactin response to TRH and LHRH, GRH and CRH stimulation tests were normal in both subjects. 
Table 1. Laboratory data in subjects 1 and 2

\begin{tabular}{|c|c|c|c|}
\hline & Subject 1 & Subject 2 & Reference range \\
\hline $\mathrm{WBC}\left(\times 10^{3} / \mathrm{mm}^{3}\right)$ & 4.4 & 2.1 & $3.9-9.8$ \\
\hline $\mathrm{RBC}\left(\times 10^{4} / \mathrm{mm}^{3}\right)$ & 406 & 403 & $350-510$ \\
\hline Plt $\left(\times 10^{4} / \mathrm{mm}^{3}\right)$ & 19 & 9.9 & $13-37$ \\
\hline $\mathrm{TP}(\mathrm{g} / \mathrm{dL})$ & 6 & 6 & $6.5-8.5$ \\
\hline GOT (IU/L) & 21 & 17 & $8-40$ \\
\hline GPT (IU/L) & 12 & 11 & $8-40$ \\
\hline ALP (IU/L) & 129 & 68 & $70-235$ \\
\hline CPK (IU/L) & 96 & 62 & $15-130$ \\
\hline Triglyceride $(\mathrm{mg} / \mathrm{dL})$ & 61 & 67 & $40-140$ \\
\hline Total cholesterol (mg/dL) & 193 & 156 & $150-220$ \\
\hline BUN (mg/dL) & 12 & 15 & $8-20$ \\
\hline Creatinine (mg/dL) & 0.4 & 0.5 & $0.6-1.5$ \\
\hline Iodide (mg/dL) & 6.8 & 11.8 & $4.0-9.0$ \\
\hline $\mathrm{FT}_{4}(\mathrm{ng} / \mathrm{dL})$ & 1.17 & 1.55 & $0.98-1.90$ \\
\hline $\mathrm{FT}_{3}(\mathrm{pg} / \mathrm{mL})$ & 3.95 & 4.02 & $3.30-4.93$ \\
\hline $\mathrm{TSH}(\mu \mathrm{U} / \mathrm{mL})$ & $<0.10$ & $<0.10$ & $0.48-4.2$ \\
\hline TRH (pg/mL) & 10.6 & 24.3 & $7.6-12.0$ \\
\hline $\mathrm{TBG}(\mu \mathrm{g} / \mathrm{mL})$ & 18.3 & 24.1 & $14.0-29.4$ \\
\hline $\operatorname{Tg}(\mathrm{ng} / \mathrm{mL})$ & 56 & 11 & $<33$ \\
\hline $\operatorname{TgAb}(\mathrm{U} / \mathrm{mL})$ & $<0.3$ & 17.8 & $<0.3$ \\
\hline TPOAb (U/mL) & $<0.3$ & $<0.3$ & $<0.3$ \\
\hline TRAb (\%) & 4.3 & 4.7 & $<10$ \\
\hline TSAb (\%) & 108 & 128 & $<180$ \\
\hline S-HCG (mIU/mL) & $<1.0$ & $<1.0$ & $<1.0$ \\
\hline Estradiol (pg/mL) & $<1.0$ & 80 & $*$ \\
\hline
\end{tabular}

*10-220 (ovarian follicle phase), 14-251 (luteal phase)

103-366(ovulation phase), $<18$ (postmenopause)

Table 2. TRH, LHRH, GRH and CRH stimulating test in subjects 1 and 2

Subject 1

\begin{tabular}{lrrrrc}
\hline & \multicolumn{1}{c}{0} & \multicolumn{1}{c}{30} & \multicolumn{1}{c}{60} & \multicolumn{1}{c}{90} & 120 \\
\hline TSH $(\mu \mathrm{U} / \mathrm{mL})$ & $<0.03$ & 0.78 & 0.64 & 0.46 & 0.32 \\
$\mathrm{~T}_{3}(\mathrm{pg} / \mathrm{mL})$ & 0.74 & 0.73 & 0.7 & 0.74 & 0.77 \\
PRL $(\mathrm{ng} / \mathrm{mL})$ & 2.9 & 70.2 & 44.9 & 29.2 & 15.7 \\
$\mathrm{LH}(\mathrm{mIU} / \mathrm{mL})$ & 18.9 & 42.9 & 57.1 & 58.9 & 55.4 \\
$\mathrm{FSH}(\mathrm{mIU} / \mathrm{mL})$ & 68.6 & 75.7 & 83.3 & 85.3 & 87.4 \\
$\mathrm{GH}(\mathrm{ng} / \mathrm{ml})$ & 0.57 & 37.35 & 29.63 & 13.79 & 5.51 \\
Cortisol $(\mu \mathrm{g} / \mathrm{dL})$ & 3.6 & 15.3 & 15.4 & 15.9 & 15.8 \\
\hline
\end{tabular}

\begin{tabular}{lrrrrc} 
Subject 2 & \multicolumn{1}{c}{} & & & & (min) \\
\hline & \multicolumn{1}{c}{0} & \multicolumn{1}{c}{30} & \multicolumn{1}{c}{60} & \multicolumn{1}{c}{90} & 120 \\
\hline $\mathrm{TSH}(\mu \mathrm{U} / \mathrm{mL})$ & $<0.03$ & $<0.03$ & $<0.03$ & $<0.03$ & $<0.03$ \\
$\mathrm{~T}_{3}(\mathrm{pg} / \mathrm{mL})$ & 1.2 & 1.24 & 1.26 & 1.23 & 1.21 \\
$\mathrm{PRL}(\mathrm{ng} / \mathrm{mL})$ & 3.4 & 84.2 & 52.3 & 35.3 & 22.9 \\
$\mathrm{LH}(\mathrm{mIU} / \mathrm{mL})$ & 11.2 & 56.4 & 48.7 & 39.4 & 36.8 \\
$\mathrm{FSH}(\mathrm{mIU} / \mathrm{mL})$ & 10.6 & 20.4 & 22 & 22.4 & 21.5 \\
$\mathrm{GH}(\mathrm{ng} / \mathrm{mL})$ & 2.8 & 10.4 & 23.9 & 32.4 & 14.4 \\
Cortisol $(\mu \mathrm{g} / \mathrm{dL})$ & 11.4 & 15.5 & 17.1 & 19.8 & 19.5 \\
\hline
\end{tabular}

\section{Imaging studies}

An ultrasonographic study of the thyroid in subject 1 showed an enlarged gland with multiple small cysts. $\mathrm{V}_{\max }$ of the inferior thyroid artery was $32.8 \mathrm{~cm} / \mathrm{sec}$ (normal $11.2 \pm 6.0 \mathrm{~cm} / \mathrm{sec}$, Graves'disease $42.2 \pm 22.4$ $\mathrm{cm} / \mathrm{sec}$ ), while ultrasonography of subject 2's thyroid was normal. $\mathrm{V}_{\max }$ was $9.3 \mathrm{~cm} / \mathrm{sec}$. MRI of the sella and hypothalamus in both subjects revealed no abnormalities (images not shown).

Both subjects had several examinations indicating normal iodide transport into their thyroid glands as follows: Autonomously functioning thyroid lesions (AFTL) [13] were not detected by ${ }^{99} \mathrm{~m} \mathrm{TcO}_{4}{ }^{-}$and ${ }^{123} \mathrm{I}$ thyroid images. Ectopic thyroids were not detected by ${ }^{99} \mathrm{mcO}_{4}^{-}$and ${ }^{123} \mathrm{I}$ total body scans. ${ }^{99} \mathrm{~m} \mathrm{TcO}_{4}^{-}$thyroid uptake and imaging studies were performed 7 times in subject 1 during the 1983-2003 period. Diffuse goiter and salivary gland uptake were always seen. The ${ }^{99} \mathrm{mcO}_{4}^{-}$thyroid uptake was $0.48 \pm 0.36 \%$ (mean \pm S.D., range $0.1-1.1 \%$ ). ${ }^{123}$ I thyroid images at 24 -hour showed a diffusely enlarged goiter with a normal uptake of $17.9 \%$ in subject 1 (Fig. 2, right upper panel). This was performed 4 times during the 1988-2003 period with a mean uptake of $16 \pm 2.8 \%$ (range, 12 $18 \%$ ). In subject 2 in 2001 the ${ }^{99} \mathrm{TcO}_{4}{ }^{-}$thyroid uptake was $0.2 \%$ and the 24 -hour ${ }^{123}$ I thyroid image showed a moderately enlarged diffuse goiter with a normal iodine uptake of $21.7 \%$ (Fig. 2, right lower panel).

The results of a $T_{3}$ suppression test in both subjects are shown in Table 3. ${ }^{123}$ I thyroid uptake in subject 1 was decreased from $17.9 \%$ to $9.5 \%$ by administering $75 \mu \mathrm{g} /$ day $\mathrm{T}_{3}$ for 7 days. In subject $2,{ }^{123}$ I thyroid uptake was unchanged after $T_{3}$ administration. Serum total cholesterol and triglyceride in both subjects were significantly decreased, while the low TSH remained unchanged.

The maximal perchlorate discharge in subject 1 was $9.7 \%$ within $60 \mathrm{~min}$ of oral administration of $\mathrm{ClO}_{4}^{-}$ compared to $4.5 \pm 4.3 \%$ (range $0-9.9 \%$ ) in controls.

\section{In vitro studies}

When graduated amounts of standard hTSH were added to the subjects' sera in vitro, the recoveries were $60.8-101.7 \%$ in subject 1 and $79.7-123.3 \%$ in subject 2 (Table 4). HAMA and anti-TSH antibody were negative. No mutations were detected in the sequence of the TSH $\beta$ gene in subject 1. 
Table 3. $\mathrm{T}_{3}$ suppression test

Subject 1

\begin{tabular}{lrrc}
\hline & Before $\mathrm{T}_{3}$ & After $_{3}$ & $\begin{array}{c}\text { Reference } \\
\text { range }\end{array}$ \\
\hline $\mathrm{FT}_{4}(\mathrm{ng} / \mathrm{dL})$ & 1.14 & 1.29 & $0.98-1.90$ \\
$\mathrm{FT}_{3}(\mathrm{pg} / \mathrm{mL})$ & 4.5 & 16.1 & $3.30-4.93$ \\
$\mathrm{~T}_{4}(\mu \mathrm{g} / \mathrm{dL})$ & 7.4 & 6.7 & $5.9-12.3$ \\
$\mathrm{~T}_{3}(\mathrm{ng} / \mathrm{mL})$ & 0.96 & 4 & $0.8-1.8$ \\
$\mathrm{TSH}(\mu \mathrm{U} / \mathrm{mL})$ & $<0.03$ & $<0.03$ & $0.48-4.2$ \\
Total cholesterol $(\mathrm{mg} / \mathrm{dL})$ & 199 & 143 & $150-220$ \\
Triglyceride $(\mathrm{mg} / \mathrm{dL})$ & 60 & 34 & $40-140$ \\
ALP $(\mathrm{IU} / \mathrm{L})$ & 125 & 130 & $70-235$ \\
Ferritin $(\mathrm{ng} / \mathrm{mL})$ & 49 & 70 & $10-100$ \\
$24 \mathrm{~h}^{123} \mathrm{I}$ thyroid uptake $(\%)$ & 17.9 & 9.5 & $7-35$ \\
\hline
\end{tabular}

Subject 2

\begin{tabular}{lrrc}
\hline & Before $\mathrm{T}_{3}$ & After $_{3}$ & $\begin{array}{c}\text { Reference } \\
\text { range }\end{array}$ \\
\hline $\mathrm{FT}_{4}(\mathrm{ng} / \mathrm{dL})$ & 1.75 & 1.94 & $0.98-1.90$ \\
$\mathrm{FT}_{3}(\mathrm{pg} / \mathrm{mL})$ & 5.91 & 17.6 & $3.30-4.93$ \\
$\mathrm{~T}_{4}(\mu \mathrm{g} / \mathrm{dL})$ & 12.4 & 12.7 & $5.9-12.3$ \\
$\mathrm{~T}_{3}(\mathrm{ng} / \mathrm{mL})$ & 1.33 & 5.27 & $0.8-1.8$ \\
$\mathrm{TSH}(\mu \mathrm{U} / \mathrm{mL})$ & $<0.03$ & $<0.03$ & $0.48-4.2$ \\
Total cholesterol $(\mathrm{mg} / \mathrm{dL})$ & 186 & 161 & $150-220$ \\
Triglyceride $(\mathrm{mg} / \mathrm{dL})$ & 64 & 41 & $40-140$ \\
ALP $(\mathrm{IU} / \mathrm{L})$ & 108 & 105 & $70-235$ \\
Ferritin $(\mathrm{ng} / \mathrm{mL})$ & 49 & 16 & $10-100$ \\
$24 \mathrm{~h}{ }^{123} \mathrm{I} \mathrm{thyroid} \mathrm{uptake}(\%)$ & 16 & 18 & $7-35$ \\
\hline
\end{tabular}

Table 4. Recovery of hTSH added to the patients' sera

\begin{tabular}{cccc}
\hline Subject & $\begin{array}{c}\text { TSH added } \\
(\mu \mathrm{U} / \mathrm{mL})\end{array}$ & $\begin{array}{c}\text { Serum TSH measured } \\
(\mu \mathrm{U} / \mathrm{mL})\end{array}$ & $\begin{array}{c}\text { Recovery } \\
(\%)\end{array}$ \\
\hline 1 & 0 & 0 & \\
& 0.74 & 0.45 & 60.8 \\
& 2.45 & 2.03 & 82.9 \\
& 7.1 & 6.99 & 98.5 \\
& 24 & 24.4 & 101.7 \\
2 & 0 & 0 & \\
& 0.74 & 0.59 & 79.7 \\
& 2.45 & 2.66 & 108.6 \\
& 7.1 & 8.55 & 120.4 \\
& 24 & 29.6 & 123.3 \\
\hline
\end{tabular}

\section{Discussion}

We encountered two subjects with persistently undetectable TSH, but with almost normal free thyroid hormone levels. They were asymptomatic and biochemically euthyroid and remained so during the sev- eral years of observation.

These results indicated that our patients do not secrete immunologically active TSH. We can almost completely exclude the possibility that the patients have an immunologically inactive, biologically active form of TSH. First, the TSH gene is normal, at least in subject 1 , and so its hypothetical form would need to arise from abnormal posttranslational processing. Second, the TSH immunoassay reacts with protein epitopes, and so variant carbohydrate processing would not explain the results. Third, there was no increase in $\mathrm{T}_{3}$ after TRH, a stimulus that would have increased the concentration of an abnormal but active TSH. Therefore, we believe that the maintenance of thyroid gland activity in these subjects is independent of TSH and must be controlled by other factors. This factor does not appear to be TSAb as we measured its level frequently.

Their ${ }^{123}$ I thyroid uptakes were normal despite undetectable TSH. There were discrepancies in both subjects between low ${ }^{99} \mathrm{TcO}_{4}{ }^{-}$and normal ${ }^{123} \mathrm{I}$ thyroid uptakes. ${ }^{99} \mathrm{~m} \mathrm{TcO}_{4}^{-}$was trapped in the thyroid but not organized into thyroid hormones like ${ }^{123} \mathrm{I}$, and the normal range of ${ }^{99} \mathrm{mcO}_{4}^{-}$was low and narrow $(0.4-$ $2.5 \%$ ). To evaluate thyroid function ${ }^{123} \mathrm{I}$ uptake is regarded to be more reliable than ${ }^{99} \mathrm{mcO}_{4}^{-}$. We have observed two overt hyperthyroidism patients with normal or high ${ }^{123} \mathrm{I}$ and low ${ }^{99} \mathrm{TcO}_{4}{ }^{-}$uptake [14].

The cause of the low TSH in our subjects is unclear. This might be related to an abnormal lower setting of pituitary threshold of TSH suppression only to thyroid hormone. Only point of difference in these two subjects is the result of $T_{3}$ suppression test. $T_{3}$ suppression test is borderline positive in subject 1 and negative in subject 2 . It should be noted that the factor in subject 1 was under physiological control, as thyroid uptake of iodine was suppressed by excess $\mathrm{T}_{3}$. Low TSH by aging thyroid was reported by Mariotti et al. [10]. They reported that both serum $\mathrm{FT}_{3}$ and TSH levels of centenarians were statistically lower than adult control groups. Subject 1 is an elderly subject and there seems no possibility of age-dependent decrease of TSH because her $\mathrm{FT}_{3}$ has been normal and the undetectable TSH levels have continued for 19 years since 1985 .

In subject 2, an unknown thyroid stimulating factor might be stronger than that in subject 1 and not suppressed by $T_{3}$. One possibility is the recently reported thyrostimulin. Two novel human heterodimeric glycoprotein subunits genes, $A_{2}$ and $B_{5}$, have been recently 
identified by Nakabayashi et al. [15]. They demonstrated that $\mathrm{A}_{2} / \mathrm{B}_{5}$ pair can stimulate cAMP production via the TSH receptor and increase serum $\mathrm{T}_{4}$ levels in rats. This new pituitary hormone, termed thyrostimulin, may change our established view of the hypothalamic-pituitary thyroid axis.

Autoantibodies against thyroid hormones, TSH [16] and HAMA [17] can produce false immunoassay results. We assayed free thyroid hormones using Amerlex-MAB FT $4, \mathrm{FT}_{3}$ kits, which are not affected by anti- $\mathrm{T}_{4}$ and anti- $\mathrm{T}_{3}$ antibodies [18]. HAMA and antiTSH antibodies were both negative and these factors produced spuriously elevated TSH values. Percentage of recovery of both subjects upon addition of a small amount of standard TSH was somewhat low but satisfactory at increased levels of TSH. The possibility that our patients' sera contained another factor that caused falsely low TSH immunoassay results is excluded by our recovery experiments. The subjects were not taking any medications, except for Kaufmann treatment sometimes taken by subject 2 . There is no reason to suspect that estrogen and estradiol caused the low TSH levels.

Despite the absence of TSH, subject 1 had a goiter with increased blood flow, as shown by the measured $\mathrm{V}_{\max }$ in the inferior thyroid artery. The boderline result of the perchlorate discharge test in this patient is not clear. These two subjects had very similar thyroid function tests although subject 1 showed a minimal TSH response to TRH and subject 2 showed no response. The lack of increase in $\mathrm{T}_{3}$ was in accord with the minimal or absent TSH response to TRH. In hypothyroid patients a rise in serum TSH after TRH administration is suggestive of hypothalamic hypothyroidism while the lack of a TSH response suggests pituitary hypothyroidism. These data could suggest that the subjects had central hypothyroidism.

Initially, TRH deficiency was suspected in subject 1 and isolated TSH deficiency was suspected in subject 2. However, neither of the subjects was hypothyroid during prolonged observation nor did they have any other evidence of hypothalamic-pituitary dysfunction.

Did the subjects have a subtle form of hyperthyroidism? The various possibilities in this category, euthyroid Graves' disease [1], subclinical thyrotoxicosis [2], destructive thyroiditis [3], and extrathyroidal thyrotoxicosis [4-6], were ruled out by normal thyroid hormone levels, normal thyroid and total body scans with ${ }^{123} \mathrm{I}$ and ${ }^{99} \mathrm{~m} \mathrm{TcO}_{4}^{-}$. Although they have neither TSH nor TSAb secretion, they are euthyroid. This suggests that an unknown thyroid-stimulating factor, such as thyrostimulin [12], maintains their thyroid function.

In summary, despite the absence of TSH, the thyroid gland in these patients functions normally and is suppressed by $\mathrm{T}_{3}$, consistent with this hypothesis. Until the pathophysiology of this condition is better understood, we suggest calling this form of long-term euthyroidism with low TSH as "euthyroid-low TSH syndrome".

\section{Acknowledgments}

We are grateful to Dr. Arthur B. Schneider, Professor of Medicine, University of Illinois College of Medicine, Chicago, for his valuable advice and discussion.

\section{References}

1. Gorman CA (1983) Temporal relationship between onset of Graves' ophthalmopathy and diagnosis of thyrotoxicosis. Mayo Clin Proc 58: 515-519.

2. Parle JV, Franklyn JA, Cross KW, Jones SC, Sheppard MC (1991) Prevalence and follow-up of abnormal thyrotropin (TSH) concentrations in the elderly in the United Kingdom. Clin Endocrinol 34: 77-83.

3. Amino N, Yabu Y, Miyai K, Fujie T, Azukizawa M, Onishi T, Kumahara Y (1978) Differentiation of thyrotoxicosis induced by thyroid destruction from Graves' disease. Lancet 2: 344-346.

4. Cohen JH, Ingbar SH, Braverman LE (1989) Thyrotoxicosis due to ingestion of excess thyroid hormone.
Endocr Rev 10: 113-124.

5. Federman DD (1964) Hyperthyroidism due to functioning metastatic carcinoma of the thyroid. Medicine 43: $267-274$.

6. Smith FG (1946) Pathology and physiology of struma ovarii. Arch Surg 53: 603-626.

7. Kempers RD, Dockerty MB, Hoffman DL, Bartholomew LG (1970) Struma ovarii-ascitic, hyperthyroid, and asymptomatic syndromes. Ann Intern Med 72: 883-893.

8. Hershman JH (1980) Hypothalamic and pituitary hypothyroidism. In: Bastenic TA, Bonnyns M, Vanhaelst L (eds) Recent Progress in Diagnosis and Treatment of Hypothyroidism Condition. Excerpta Medica, Amster- 
dam, 40-50.

9. Franklyn JA, Black EG, Betteridge J, Sheppard MC (1994) Comparison of second and third generation methods for measurement of serum thyrotropin in patients with overt hyperthyroidism, patients receiving thyroxine therapy, and those with nonthyroidal illness. $J$ Clin Endocrinol Metab 78: 1368-1371.

10. Mariotti S, Franceschi C, Cossarizza A, Pinchera A (1995) The aging thyroid. Endocr Rev 16: 686-715.

11. Kaufmann C (1932) Umwandlung der Uterusschleimhaut einer kastrierten Frau aus dem atrophischen Stadium in das der sekretorischen Funktion durch Ovarialhormone. Zentralbl Gynakol 56: 2058-2061.

12. Inui T, Kouki T, Yamashiro K, Hachiya T, Ochi Y, Kajita Y, Sato Y, Nagata A (1998) Increase of thyroid stimulating activity in Graves' immunoglobulin-G by high polyethylene glycol concentrations using porcine thyroid cell assay. Thyroid 8: 319-325.

13. Hamburger (1980) Evolution of toxicity in solitary nontoxic autonomously functioning thyroid nodules. $J$ Clin Endocrinol Metab 50: 1089-1093.

14. Ikekubo K, Hino M, Son C, Iwakura T, Kobayashi H, Ishihara T (2003) Clinical study on painless thyroiditis. Kobe City Hosp Bull 42: 27-32 (In Japanese).
15. Nakabayashi $\mathrm{K}$, Matsumi $\mathrm{H}$, Bhalla A, Bae J, Mosselman S, Hsu SY, Hsueh JW (2002) Thyrostimulin, a heterodimer of two new human glycoprotein hormone subunits, activates the thyroidstimulating hormone receptor. J Clin Invest 109: 14451452.

16. Akamizu T, Mori T, Kasagi K, Kosugi S, Miyamoto M, Nishino K, Sugawa H, Yokota T, Nakamura H, Konishi J, et al. (1987) Anti-TSH antibody with high specificity to human TSH in sera from a patient with Graves' disease: Its isolation from, and interaction with, TSH receptor antibodies. Clin Endocrinol 26: 311-320.

17. Kahn BB, Weintraub BD, Csako G, Zweig MH (1988) Factitious elevation of thyrotropin in a new ultrasensitive assay: implications for the use of monoclonal antibodies in "sandwich" immunoassay. J Clin Endocrinol Metab 66: 526-533.

18. Ikekubo K, Hino M, Saiki Y, Kajikawa M, Hattori N, Ishihara T, Moridera K, Kurahachi H (1995) Three thyroid patients showing fluctuation of thyroid hormone autoantibody titers during long-term treatment. Folia Endocrinol Jpn 71: 695-708 (In Japanese). 